Sädhanā Vol. 38, Part 1, February 2013, pp. 3-23. (C) Indian Academy of Sciences

\title{
Indigenous development and airworthiness certification of 15-5 PH precipitation hardenable stainless steel for aircraft applications
}

\author{
ASHOK KUMAR ${ }^{1}$, Y BALAJI ${ }^{1}$, N ESWARA PRASAD ${ }^{1, *}$, \\ $\mathrm{G} \mathrm{GOUDA}^{2}$ and $\mathrm{K}$ TAMILMANI ${ }^{2}$ \\ ${ }^{1}$ Regional Centre for Military Airworthiness (Materials), CEMILAC, DRDO, \\ PO Kanchanbagh, Hyderabad 500 058, India \\ ${ }^{2}$ Centre for Military Airworthiness and Certification (CEMILAC), DRDO, \\ PO Marathahalli Colony, Bangalore 560037, India \\ e-mail: nep@cemilac.drdo.in
}

MS received 9 August 2011; revised 18 September 2012; accepted 18 January 2013

\begin{abstract}
In this paper, we discuss the optimization of chemical composition, processing (forging and rolling) and heat treatment parameters to obtain the best combination of mechanical properties in case of a $\mathrm{Fe}-15 \mathrm{Cr}-5 \mathrm{Ni}-4 \mathrm{Cu}$ precipitation hardenable stainless steel. The $\varepsilon$-copper precipitates that form during aging are spherical in shape and coherent with the matrix and principally provide strengthening in this alloy. The orientation relationship is found to be Kurdjumov-Sachs $(\mathrm{K}-\mathrm{S})$, which is common in fcc-bcc systems. Results obtained from metallurgical evaluation (mechanical property and metallography) on 15-5 $\mathrm{PH}$ alloy during type certification on 3 different melts were used for the optimization, attempted in this study. The mechanical properties following strain deformation has been carried out using optical microscope, scanning electron microscope (SEM) and transmission electron microscope (TEM). In the aged conditions, the 15-5 PH alloy exhibited brittle failure with extensive cleavage and/or quasicleavage fracture. This paper reports all results and also factually shows that indigenously developed and produced 15-5 PH stainless steel matches in its properties with the equivalent aeronautical grade precipitation hardening stainless steels globally produced by internationally renowned manufactures.
\end{abstract}

Keywords. Martensitic stainless steel 15-5 PH; processing; heat treatment; macro and micro structure; tensile properties; fatigue properties; development and certification.

\section{Introduction}

Precipitation hardenable martensitic stainless steel $15-5 \mathrm{PH}(\mathrm{Fe}-15 \mathrm{Cr}-5 \mathrm{Ni}-4 \mathrm{Cu})$ has been selected for actuator parts for modern fighter aircrafts (figure 1). This PH stainless steel exhibits

*For correspondence 

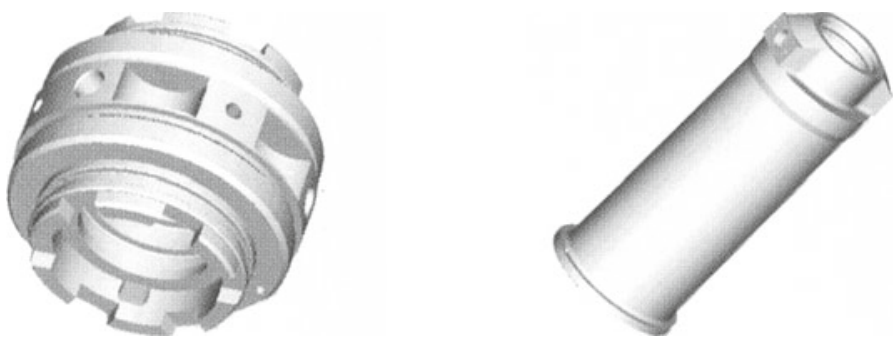

Figure 1. Actuator system components for an Indian aircraft.

excellent combination of high strength and hardness, with excellent corrosion resistance, weldability, forgeable and finally amenability to cast and machine (John \& Shannon 1969). Additional features of this alloy also include high resistance to crack propagation, good transverse properties and good resistance to stress-corrosion cracking in marine atmosphere (Armco 15-5 PH VAC $\mathrm{CE}$ ). Because of its ease of fabrication, the 15-5 PH stainless steel has been found economical and appropriate to replace low alloy carbon steels. The PH stainless steel retains useful strengths at temperatures up to $315^{\circ} \mathrm{C}$ and like other martensitic stainless steels, it undergoes a ductile brittle transition at subzero temperatures. Apart from these, the 15-5PH alloy exhibits good short transverse ductility and a reasonably high strength in large section sizes. This steel is normally used in either annealed or over-aged condition and is normally heat treated after fabrication. However, caution should be exercised as the parts of this steel should never be used in heat treatment condition A (the details of which are given in section 3.1). When good fracture toughness or impact toughness is required, both at and below room temperature, heat treatment conditions H900 and H925 should be used (see section 3.1 for details of the heat treatments). Heat treatment conditions $\mathrm{H} 1025, \mathrm{H} 1075, \mathrm{H} 1100$ and $\mathrm{H} 1150$ provide lower transition temperatures and hence are more useful for fracture toughness critical applications as compared to the H900 and H925 conditions. The H1150M condition results best notch toughness and is recommended for cryogenic applications.

Based on the criticality of the application, the integrity verifications in each melt and consistency verifications on a minimum of three different melts were deemed appropriate for certification exercise from virgin raw materials (Type Test Schedule 2001). Scrap was also used for making the production of this steel economical.

\section{Manufacturing}

Electric arc furnace was used for taking the primary melt of the alloy with charge calculations in accordance with the composition as per approved documents. Suitable additions were made and the charge was cast in the form of electrodes. After conditioning of electrodes, they were remelted in Vacuum Arc Remelting (VAR) furnace in order to achieve homogenous ingot without the internal defects and segregation. A systematic process flow chart for manufacturing of 15-5 PH martensitic stainless steel was adopted and the same is shown in figure 2.

$15-5 \mathrm{PH}$ is readily forged and welded. Forging procedures are similar to those used for 17 $4 \mathrm{PH}$, the forgeability of $15-5 \mathrm{PH}$ being superior to that of $17-4 \mathrm{PH}$ in critical types of upsetforging and hot treating operations. Machining in the solution treated condition is done at rates similar to 304 stainless steels and 60 percent of these rates work well for condition H900. Higher 


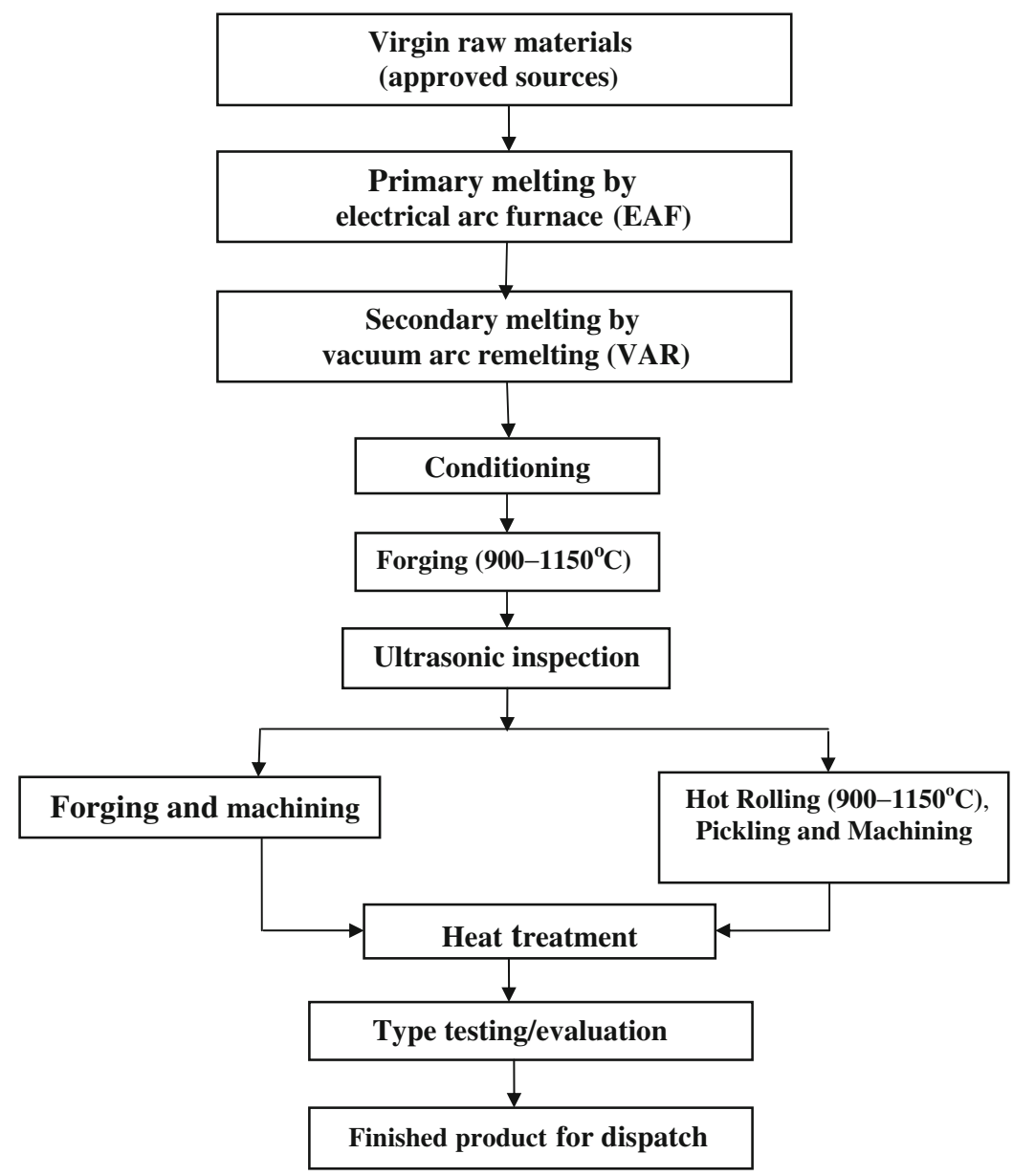

Figure 2. Process flow chart for manufacturing of 15-5 PH martensitic stainless steel.

machining rates are found to be possible with conditions H1150 and H1150 M. Material which is hot worked must be solution treated before hardening. A dimensional contraction of 0.010 to 0.015 and 0.020 to $0.0254 \mathrm{~mm} / \mathrm{mm}$ will occur on hardening to the steel in $\mathrm{H} 900$ and $\mathrm{H} 1150$ conditions, respectively, which should be taken into account while finalizing the hot workable stock to yield required final product sizes.

The ingots were forged while controlling the critical factors such as heating, cooling and scaling rated in accordance with the approved processing schedule (Type Approval Document 2004). The resulting billets were ground and ultrasonically tested before transferring for hot rolling. At each stage, hardness checks were conducted to verify appropriate supply condition.

The corrosion resistance of $15-5 \mathrm{PH}$ is found to be comparable to that of 17-4PH (Product Data Sheet of 15-5 PH Stainless Steel 2007). Hence, for applications where stress corrosion is a possibility, $15-5 \mathrm{PH}$ should be aged at the highest temperature that is compatible with strength requirements and at a temperature not lower than $550^{\circ} \mathrm{C}$ and for a minimum aging time of $4 \mathrm{~h}$. 


\section{Aerospace specifications}

Aerospace material specifications for $15-5 \mathrm{PH}$ are specified in table 1 and these specifications were found to be significantly different for different product forms.

\subsection{Heat treatments}

As stated earlier, 15-5PH must be used in the heat treated condition and should not be placed in service in Condition 'A' (see the exact details given below). The alloy can be heat treated to various strength levels having wide range of properties. The application material specification MIL-H-6875 (MIL HandBook 1993) may be referred to for specific heat treated procedures.

A) Solution Treatment (Condition 'A')

$1038 \pm 14^{\circ} \mathrm{C} / \mathrm{min} 30 \mathrm{~min}+$ cool below $32^{\circ} \mathrm{C} / \mathrm{OQ}$ or $\mathrm{AC}$

B) Precipitation Treatments

$\mathrm{H} 900: 482 \pm 6^{\circ} \mathrm{C}$ for $1 \mathrm{~h} / \mathrm{AC}$

$\mathrm{H} 925: 496 \pm 6^{\circ} \mathrm{C}$ for $4 \mathrm{~h} / \mathrm{AC}$

$\mathrm{H} 1025: 552 \pm 6^{\circ} \mathrm{C}$ for $4 \mathrm{~h} / \mathrm{AC}$

$\mathrm{H} 1075: 579 \pm 6^{\circ} \mathrm{C}$ for $4 \mathrm{~h} / \mathrm{AC}$

$\mathrm{H} 1100: 593 \pm 6^{\circ} \mathrm{C}$ for $4 \mathrm{~h} / \mathrm{AC}$

$\mathrm{H} 1150: 621 \pm 6^{\circ} \mathrm{C}$ for $4 \mathrm{~h} / \mathrm{AC}$

$\mathrm{H} 1150 \mathrm{M}$ (double overage): $760 \pm 6^{\circ} \mathrm{C}$ for $2 \mathrm{~h} / \mathrm{AC}$ followed by $621 \pm 6^{\circ} \mathrm{C}$ for $4 \mathrm{~h} / \mathrm{AC}$ (where

'OQ' refers to oil quenched and 'AC' to air cool).

\subsection{Metallurgical evaluation for certification}

In order to maintain the desired quality of steel, a rigorous quality assurance programme was adopted from raw material stage to finished products and at each stage during production extensive property evaluation was conducted to adjudge the material capability.

Chemical analysis of the elements like manganese, silicon, chromium, nickel, molybdenum, tantalum, columbium and copper was carried out using optical emission spectrometer as per ASTM E 353 (ASTM E353 1993). Carbon and Sulphur were analysed using Leco Carbon and Sulphur analyzer as per ASTM standard ASTM E-1019 (ASTM E 1019 2003). Macrostructural evaluation was carried out in accordance with ASTM A-604 (ASTM A-604 2007). Microstructural characteristics and grain size were determined in both solution treated condition and in precipitation heat treatment in the final product forms as per ASTM E-112 (ASTM E 112 1996). Non metallic inclusions were rated in accordance with method D of ASTM E-45 (ASTM E45 1997). Delta-ferrite content was measured in accordance with AMS Standard AMS 2315E (AMS 2315E 2001). Mechanical properties, viz., Brinell hardness as per ASTM E-10 (ASTM

Table 1. Aerospace material specifications for $15-5 \mathrm{PH}$ stainless steel.

\begin{tabular}{ll}
\hline Specification & \multicolumn{1}{c}{ Form } \\
\hline AMS 5659 & Bar, forging, ring and extrusion $\left(\mathrm{CEVM}^{*}\right)$ \\
AMS 5862 & Sheet, strip and plate $\left(\mathrm{CEVM}^{*}\right)$ \\
AMS 5400 & Investment casting \\
\hline
\end{tabular}

*Consumable electrode vacuum melting 
Table 2. Processing stages with the quality assurance for airworthiness certification of $15-5 \mathrm{PH}$ stainless steel.

\begin{tabular}{|c|c|c|}
\hline Processing stage & Challenges & $\begin{array}{l}\text { Means to overcome the challenges } \\
\text { (Quality assurance) }\end{array}$ \\
\hline $\begin{array}{l}\text { Source of raw } \\
\text { materials } \\
\text { (Approved } \\
\text { aeronautical } \\
\text { store) }\end{array}$ & $\begin{array}{l}\text { To analyse as per } \\
\text { aeronautical } \\
\text { specification }\end{array}$ & $\begin{array}{l}\text { - Usage of } 100 \% \text { virgin raw materials. } \\
\text { - Supplier analysis (all the raw material) } \\
\text { at storage place. } \\
\text { - Repeat/confirmation of analysis is carried } \\
\text { out by user and producer agencies. } \\
\text { - Raw materials to meet AMS } 2280 \\
\text { (aeronautical) standards. } \\
\text { - All the trace and tramp element are to be } \\
\text { analyzed in ppm level and should meet } \\
\text { the specified limits as per aerospace } \\
\text { standard. } \\
\text { - All the deleterious elements are analyzed } \\
\text { and shall not be more than the } \\
\text { specified limits. } \\
\text { - All the records are to be checked and } \\
\text { verified (if found satisfactory) } \\
\text { before the release of raw material } \\
\text { for processing. }\end{array}$ \\
\hline $\begin{array}{l}\text { Primary melting } \\
\text { (Electric arc } \\
\text { furnace) }\end{array}$ & $\begin{array}{l}\text { To achieve chemistry as per } \\
\text { aeronautical material standard } \\
\text { (narrow scatter band) and } \\
\text { consistency in three } \\
\text { melts for type testing. }\end{array}$ & $\begin{array}{l}\text { - Charge calculation. } \\
\text { - Nb/C ratio shall be less than } 6 \% \text {. } \\
\text { - Maintain liquid temperature around } 1470^{\circ} \mathrm{C} \text {. } \\
\text { - Materials shall be melted according to } \\
\text { approved process sheet to without } \\
\text { any deviation. } \\
\text { - If found to have any deviation that may } \\
\text { affect material property, significantly } \\
\text { this stock is outrightly rejected. }\end{array}$ \\
\hline $\begin{array}{l}\text { Secondary melting } \\
\text { (Vacuum arc } \\
\text { remelting or } \\
\text { vacuum arc } \\
\text { refining) }\end{array}$ & $\begin{array}{l}\text { To achieve chemistry (in } \\
\text { narrow scatter band) and } \\
\text { gases content should be } \\
\text { lower than the limits } \\
\text { specified for } \mathrm{H}_{2}, \mathrm{O}_{2} \\
\text { and } \mathrm{N}_{2}\end{array}$ & $\begin{array}{l}\text { Process sheet is well defined } \\
\text { and strictly followed with } \\
\text { - Controlled vacuum level } \\
\text { - Leak rate ensured to be } \\
<10 \text { microns/minute } \\
\text { - Melt chemistry } \\
\{\text { Fe-0.05C-15Cr-5Ni-5XC }(\mathrm{Nb})\} \\
\text { - Ingot surface and its soundness } \\
\text { - Temperature control and other } \\
\text { process parameters } \\
\text { - Identification of Ingot top, } \\
\text { middle and bottom. }\end{array}$ \\
\hline Forging & $\begin{array}{l}\text { To achieve best combination of } \\
\text { mechanical and metallurgical } \\
\text { properties on forged product } \\
\text { without any defects and also } \\
\text { a quality that is consistent. }\end{array}$ & $\begin{array}{l}\text { Process sheet should be well defined } \\
\text { and strictly followed and no } \\
\text { deviation is allowed. The } \\
\text { following are ensured: } \\
\text { - Furnace atmosphere-oxidizing } \\
\text { - Heating and cooling cycles as per } \\
\text { specification }\end{array}$ \\
\hline
\end{tabular}


Table 2. (Continued).

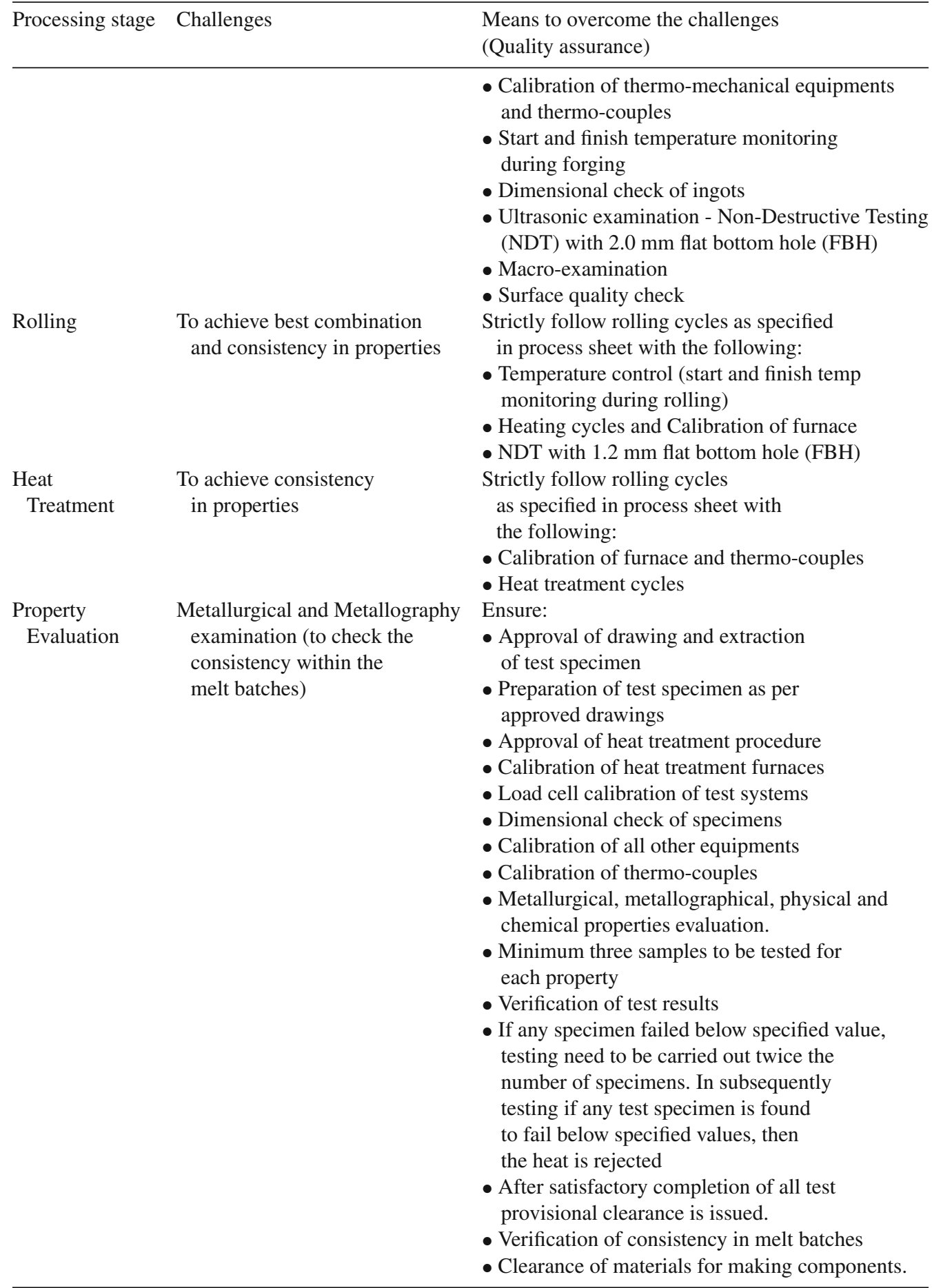


Table 2. (Continued).

\begin{tabular}{lll}
\hline Processing stage & Challenges & $\begin{array}{l}\text { Means to overcome the challenges } \\
\text { (Quality assurance) }\end{array}$ \\
\hline Type Approval & Airworthiness & - Type testing of three different melts batches. \\
Certification & Checking of properties with aerospace standard \\
and type test schedule & - After satisfactory completion of all tests provisional \\
& clearance is issued. \\
& - Verification of consistency in melt batches \\
& - Clearance of materials for making components. \\
& - Obtaining performance certificate from user that \\
& components made out of this alloy \\
& is working satisfactorily. \\
& - Issuance of type approval. \\
& - Issue of Qualification Requirements. \\
& - Regular production as per QR. \\
\hline
\end{tabular}

E10 1998), tensile properties at ambient temperature as per ASTM E8 (ASTM E8 2004) and elevated temperature tensile properties as per ASTM E-21 (ASTM E21 1998) were evaluated and reported. Both ambient and elevated temperature tensile tests were done on specimens with gage length that is 4 times the gage diameter, in accordance with the ASTM standards E8 and E21. Impact strength was determined in accordance with BS 5S100 (BS-5S100 1993) and fatigue tests were carried out in accordance with ASTM E466 (ASTM E 466 2007). The ultrasonic inspection was carried out in accordance with AMS 2630B (AMS 2630B 1995), using $2 \mathrm{~mm}$ or $1.2 \mathrm{~mm}$ flat bottom hole $(\mathrm{FBH})$ as reference standard at the intermediate stage of processing on forged bars and hot rolled bars, respectively. Sizes and tolerances were measured and verified in accordance with AMS standard 2241 (AMS 2241N 2003). Packing and forwarding was done in accordance with MIL-STD-163 standard (MIL Standard 1988). Due to high criticality of application, integrity verification in each melt and consistent verification of three melts has been

Table 3. Chemical composition of 15-5 PH martensitic stainless steel.

\begin{tabular}{lcccc}
\hline & $\begin{array}{c}\text { Specified as per AMS } \\
\text { Elements }\end{array}$ & $\begin{array}{c}\text { Specified as per } \\
\text { type test schedule }\end{array}$ & \multicolumn{2}{c}{ Obtained values (average of three melts) } \\
\cline { 5 - 5 } & 5659 H standard & Forged bars & Hot rolled bars \\
\hline Carbon & 0.07 & 0.07 & $0.045-0.047$ & 0.059 \\
Silicon & 1.00 & 1.00 & $0.14-0.57$ & $0.35-0.57$ \\
Manganese & 1.00 & 1.00 & $0.65-0.67$ & $0.54-0.67$ \\
Phosphorus & 0.030 & 0.030 & $0.012-0.018$ & $0.014-0.02$ \\
Sulphur & 0.015 & 0.015 & $0.008-0.015$ & $0.008-0.015$ \\
Chromium & $14.0-15.50$ & $14.0-15.50$ & $14.37-14.66$ & $14.50-14.91$ \\
Molybdenum & 0.50 & 0.50 & 0.02 & 0.02 \\
Copper & $2.50-4.50$ & $2.50-4.50$ & $3.23-3.30$ & $3.23-3.30$ \\
Nickel & $3.50-5.50$ & $3.50-5.50$ & $4.69-4.93$ & $4.69-4.91$ \\
Niobium & $5 \times-0.45$ & $5 x C-0.45$ & $0.28-0.35$ & $0.28-0.40$ \\
Tantalum & 0.05 & 0.05 & $<0.05$ & $<0.05$ \\
Iron & Balance & Balance & Balance & Balance \\
\hline
\end{tabular}




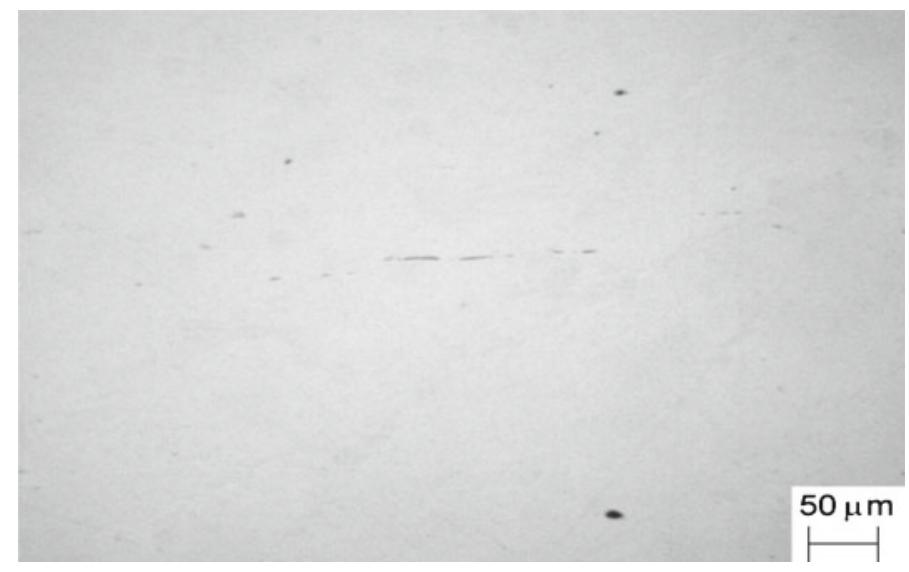

Figure 3. Optical micrograph showing elongated sulphides and globular oxide inclusions (volume fraction of inclusions is $0.08 \%$ ) in $\mathrm{H} 1025$ condition.

decided for the type certification. In order to maintain the desired quality, rigorous quality assurance steps were adopted from raw material stage to finished product, at each successive stage of production and type certification, as given in table 2. Table 2 also discusses point-wise not only all the important challenges of alloy development and aero certification, but also provides detailed means to overcome the enlisted challenges.

\section{Results and discussions}

\subsection{Chemical composition}

In order to closely control the chemistry of the alloy, all the raw materials were procured from the approved source of aeronautical grade materials. They were then primary electrical melted

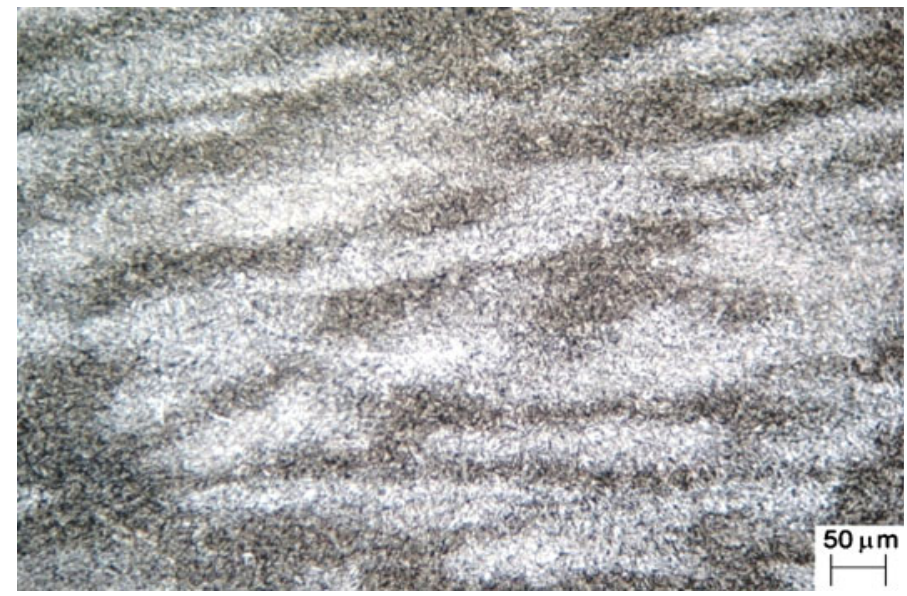

Figure 4. Optical micrograph showing microstructural banding induced by chemical segregation in $\mathrm{H}$ 1025 condition. 


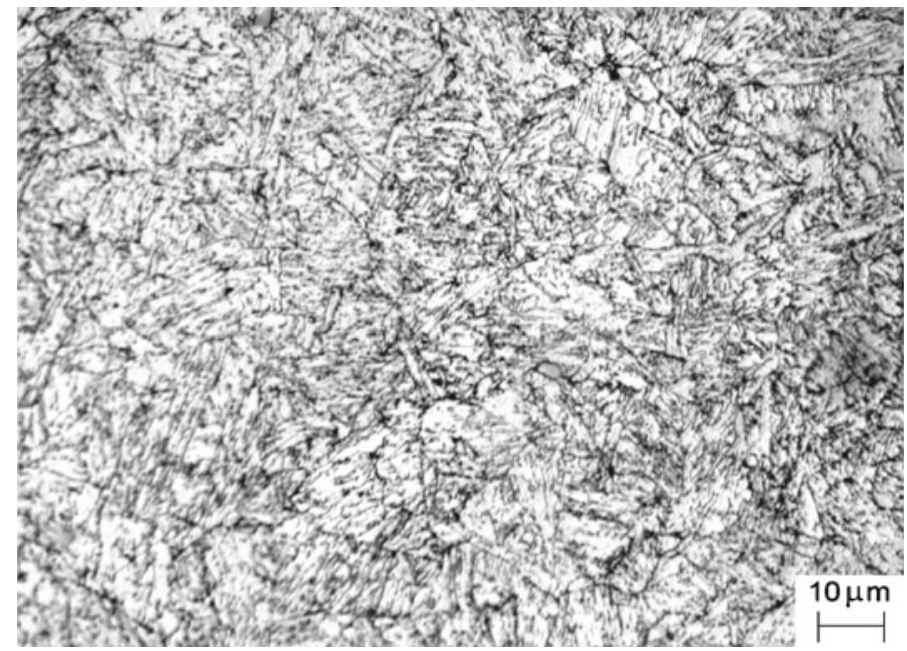

Figure 5. Optical micrograph showing lath martensite and fine carbides in H 1025 condition. The prior austenite grain size is about $14 \mu \mathrm{m}$.

and further re-melted in the vacuum furnace to ensure extremely low level of gas content. Double melting route was also found to result in a chemical composition that lies in the tighter range and within the specified limits which are comparable to the specification as stipulated in type test schedule. The chemical composition of specified and obtained in practice are presented in table 3. Chemical composition of indigenous 15-5 PH alloy was not only found to meet aerospace specification AMS 5659L (AMS 5659L 2004) and but also type test schedule requirement for the end used product with the tolerances specified in aerospace standard AMS 2248E (AMS 2248E 2000). The chemical analysis was carried out on three specimens obtained from three different melts taken from top, middle and bottom portions of the ingot. The results

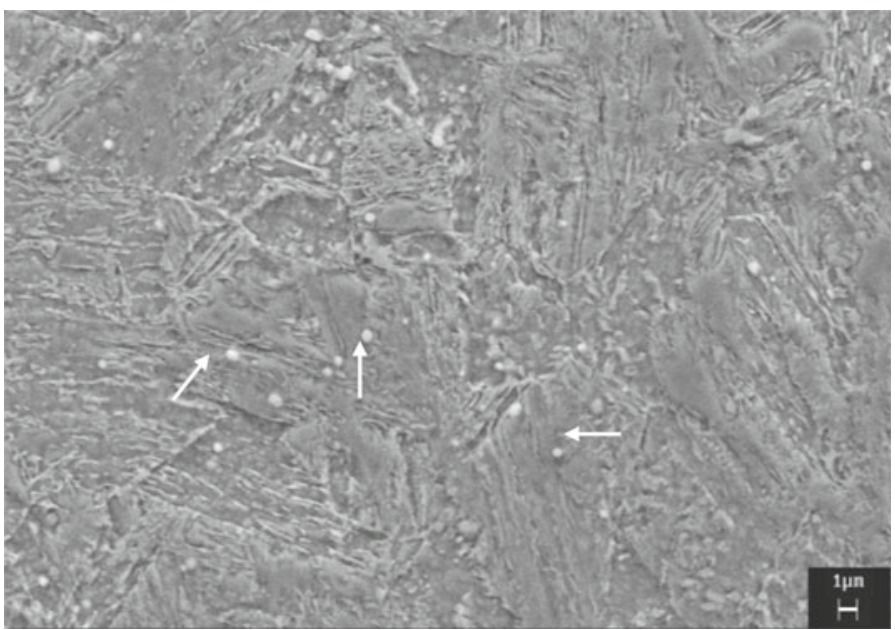

Figure 6. SEM secondary electron image showing lath martensite and several spherical carbide particles in $\mathrm{H} 1025$ condition (the carbides on EDS analysis are found to be of $\mathrm{NbC}$ type). 
obtained (see data in table 3) show that the composition is within the specified limit and in narrow scatter band.

\subsection{Microstructure}

Microstructure in the etched condition of 15-5 PH stainless steel in the H1025 precipitation hardening condition (figure 3 ) exhibits tempered martensite and prior austenite grain size was in the range of 6-7 ASTM number. The delta ferrite was found to be absent against $2 \%$ maximum

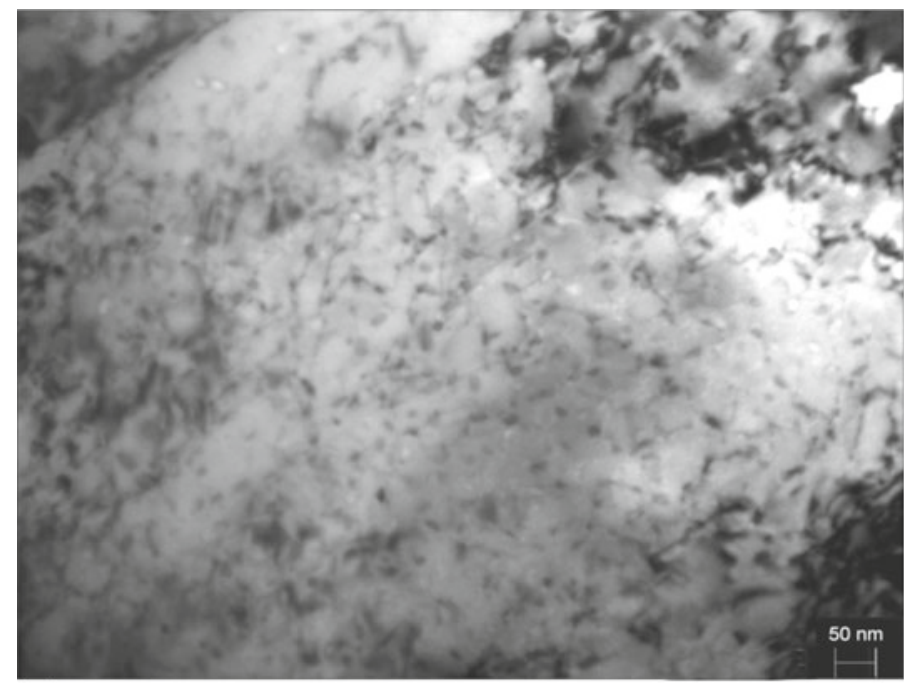

(a)

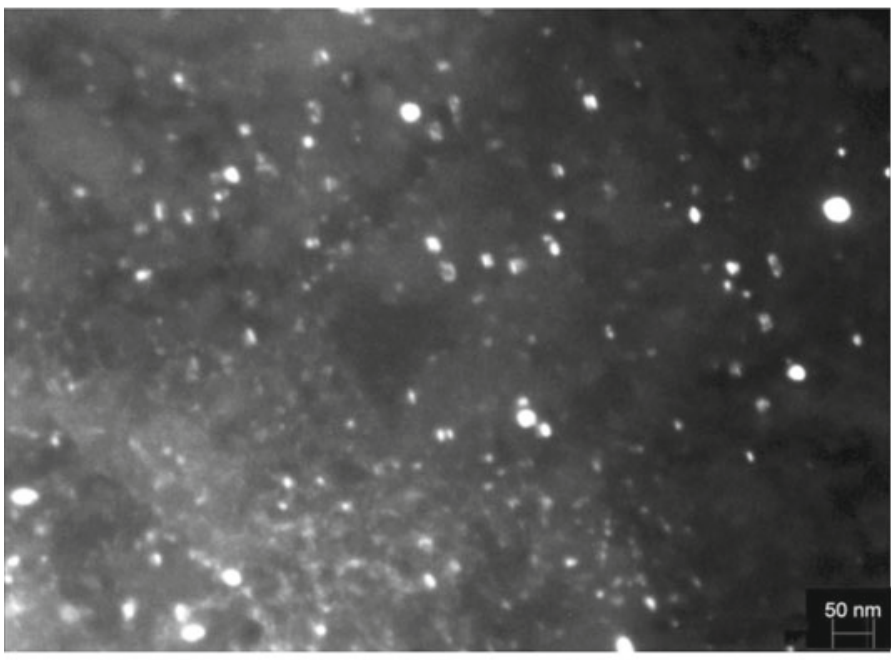

(b)

Figure 7. (a) Transmission electron micrographs showing fine spherical $\varepsilon$-copper precipitates. The average size of precipitate is about $13 \mathrm{~nm}$. (b) Transmission electron micrograph showing the dark field image of the $\varepsilon$-copper precipitates. 


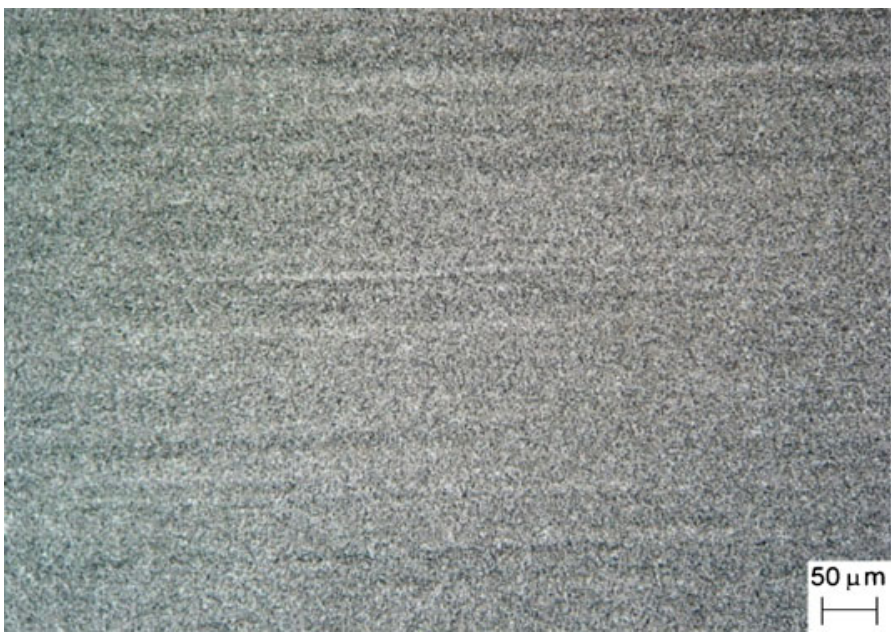

Figure 8. Optical micrograph showing microstructural banding induced by chemical segregation in H1150 condition.

specified allowable limit. The optical micrograph also shows the presence of elongated sulphides with globular oxide inclusions, having a combined volume fraction of about $0.08 \%$. Another optical micrograph (figure 4) shows banding induced by chemical segregation, in the processed condition of the steel.

The alloy was also found to have lath martensite structure with fine carbides having prior austenite grain size of about $14 \mu \mathrm{m}$ (figure 5). The scanning electron micrograph (SEM) shown in figure 6, confirmed the presence of lath martensite and spherical carbides. These carbides were found by EDS analysis as NbC. Transmission electron microscopic studies have shown the

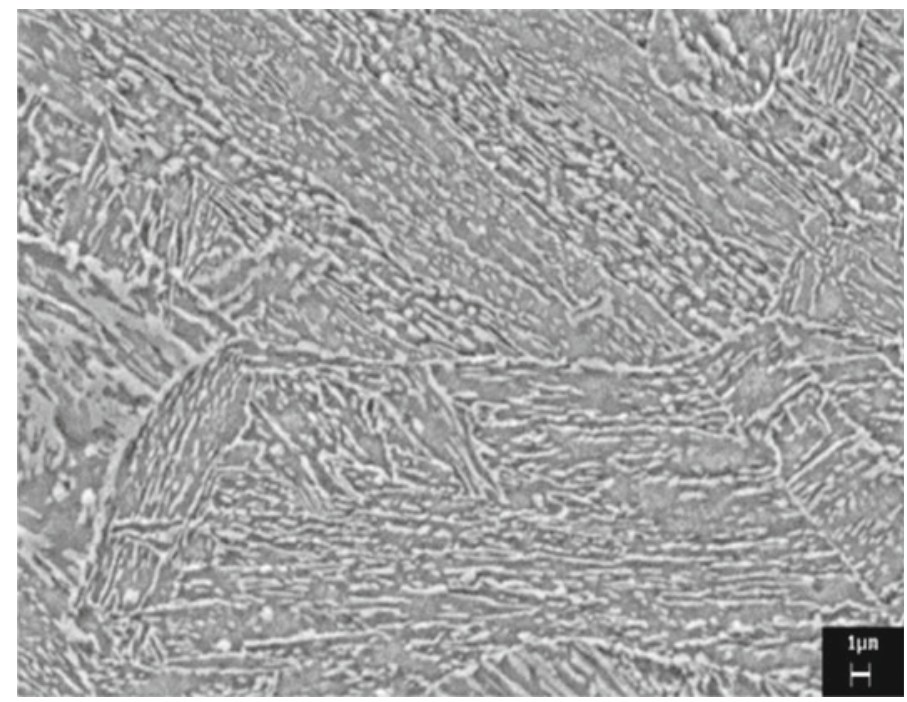

Figure 9. SEM secondary electron image showing lath martensite and fine spherical carbides of $\mathrm{NbC}$ type in $\mathrm{H} 1150$ condition. 


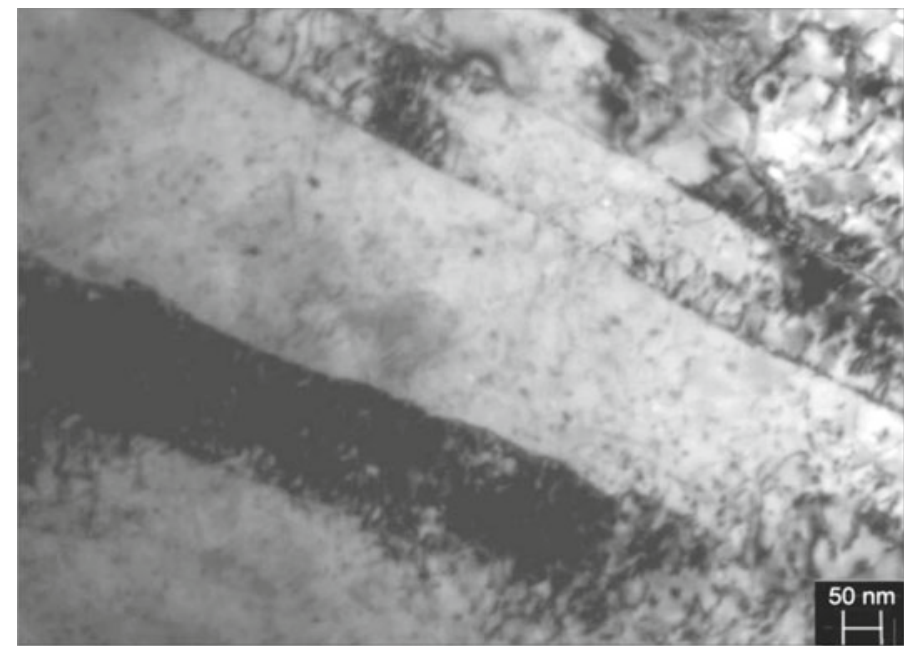

(a)

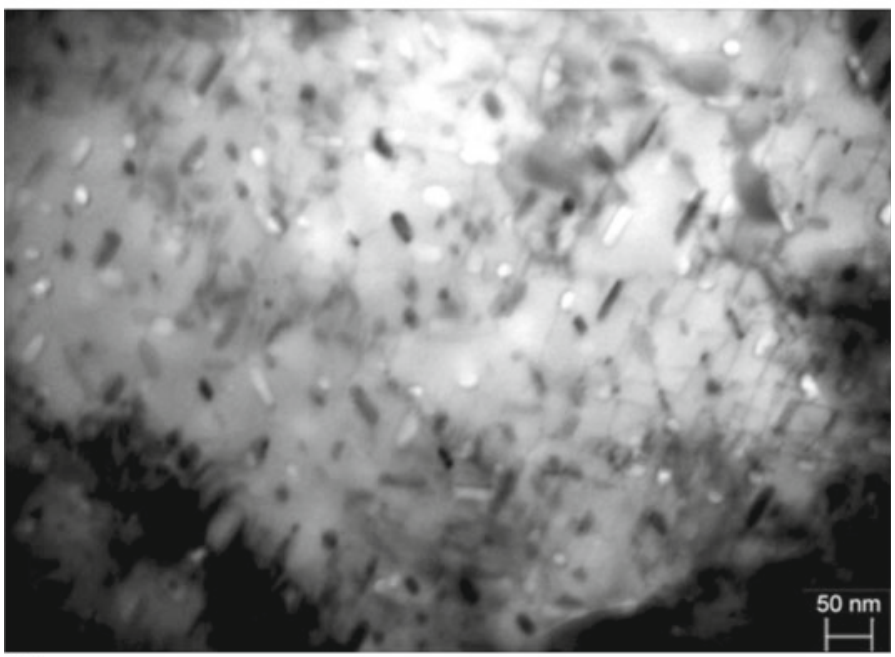

(b)

Figure 10. (a) Transmission electron micrographs showing lath martensite and fine precipitates. (b) Transmission electron micrograph showing fine elliptical $\varepsilon$-copper precipitates of about $45 \mathrm{~nm}$ length and $15 \mathrm{~nm}$ width.

Table 4. Hardness of 15-5 PH stainless steel of forged and hot rolled bars.

\begin{tabular}{lccc}
\hline Mill form & Heat treatment conditions & Specified (BHN) & Obtained (BHN) \\
\hline Forged bars & H 1025 & $331-401$ & $335-369$ \\
\multirow{3}{*}{ Hot rolled bars } & H 1150 & $277-352$ & $279-307$ \\
& H 1025 & $331-401$ & $341-373$ \\
& H 1150 & $277-352$ & $288-317$ \\
\hline
\end{tabular}


Table 5. Impact properties in joules of 15-5 PH martensitic stainless steel.

\begin{tabular}{|c|c|c|c|c|c|}
\hline \multirow{3}{*}{$\begin{array}{l}\text { Direction } \\
\text { of testing }\end{array}$} & \multirow{3}{*}{$\begin{array}{c}\text { Obtained / } \\
\text { literature values }\end{array}$} & \multicolumn{4}{|c|}{ Impact energy $(J)$ in mill forms of } \\
\hline & & \multicolumn{2}{|c|}{ Forged bars } & \multicolumn{2}{|c|}{ Hot rolled bars } \\
\hline & & H 1025 & Н 1150 & H 1025 & H 1150 \\
\hline \multicolumn{6}{|c|}{ Testing at room temperature (IZOD) } \\
\hline \multirow[t]{2}{*}{ Longitudinal } & Obtained & $51-129$ & $116-149$ & $81-140$ & $122-164$ \\
\hline & Literature $[*]$ & $171-180$ & $194-217$ & $171-180$ & $194-217$ \\
\hline \multirow[t]{2}{*}{ Transverse } & Obtained & $22-27$ & $35-42$ & - & - \\
\hline & Literature $[*]$ & $137-167$ & $188-203$ & - & - \\
\hline \multicolumn{6}{|c|}{ Testing at sub - zero temperature at $-70^{\circ} \mathrm{C}(\mathrm{CHARPY})$} \\
\hline \multirow[t]{2}{*}{ Longitudinal } & Obtained & $27-41$ & $65-129$ & $27-41$ & 99-138 \\
\hline & Literature $[*]$ & $41-51$ & $32-35$ & $41-52$ & $138-141$ \\
\hline \multirow[t]{2}{*}{ Transverse } & Obtained & $23-27$ & $27-41$ & - & - \\
\hline & Literature $[*]$ & $28-34$ & $32-35$ & - & - \\
\hline
\end{tabular}

*Product data sheet of 15-5 PH stainless steel, 2007

presence of fine spherical $\varepsilon$-copper precipitate with average precipitate size of $13 \mathrm{~nm}$ in $\mathrm{H} 1025$ condition (see figures $7 \mathrm{a}$ and $\mathrm{b}$ ).

Optical micrograph of 15-5 PH alloy in precipitation hardening H1150 condition also showed banding microstructure induced by chemical segregation (figure 8) and SEM image showed the

Table 6. Room temperature tensile properties of $15-5$ PH martensitic stainless steel.

\begin{tabular}{|c|c|c|c|c|}
\hline \multirow{2}{*}{$\begin{array}{l}\text { Tensile } \\
\text { property }\end{array}$} & \multirow{2}{*}{$\begin{array}{c}\text { As per AMS } 5659 \mathrm{H} \\
\text { specification }\end{array}$} & \multirow{2}{*}{$\begin{array}{c}\text { As per type test } \\
\text { schedule (specified) }\end{array}$} & \multicolumn{2}{|c|}{$\begin{array}{l}\text { Experimentally obtained } \\
\text { values in three melts }\end{array}$} \\
\hline & & & Forged bars & Hot rolled bars \\
\hline \multicolumn{5}{|c|}{ RT Tensile test (longitudinal) in H1025 condition } \\
\hline $0.2 \% \mathrm{PS}(\mathrm{MPa})$ & $1000 \min$ & $1000 \mathrm{~min}$ & $1050-1123$ & $1103-1134$ \\
\hline UTS (MPa) & $1069 \mathrm{~min}$ & $1069 \mathrm{~min}$ & $1096-1152$ & $1124-1175$ \\
\hline$\% \mathrm{EL}(\mathrm{Gl}=4 \mathrm{~d})$ & $12 \mathrm{~min}$ & $12 \mathrm{~min}$ & $16-20$ & $16-24$ \\
\hline$\%$ RA & $45 \min$ & $45 \min$ & $62-67$ & $66-71$ \\
\hline \multicolumn{5}{|c|}{ RT Tensile test (transverse) in H1025 condition } \\
\hline $0.2 \%$ PS (MPa) & $1000 \min$ & $1000 \mathrm{~min}$ & $1024-1088$ & - \\
\hline UTS (MPa) & $1069 \min$ & $1069 \min$ & $1083-1105$ & - \\
\hline$\% \mathrm{EL}(\mathrm{Gl}=4 \mathrm{~d})$ & $8 \min$ & $8 \mathrm{~min}$ & $14-16$ & - \\
\hline$\%$ RA & $32 \mathrm{~min}$ & $32 \mathrm{~min}$ & $34-48$ & - \\
\hline \multicolumn{5}{|c|}{ RT Tensile test (longitudinal) in H1150 condition } \\
\hline $0.2 \% \mathrm{PS}(\mathrm{MPa})$ & $724 \min$ & $724 \min$ & $725-886$ & $753-870$ \\
\hline UTS (MPa) & $931 \mathrm{~min}$ & $931 \mathrm{~min}$ & $958-984$ & $958-994$ \\
\hline$\% \mathrm{EL}(\mathrm{Gl}=4 \mathrm{~d})$ & $16 \min$ & $16 \min$ & $22-26$ & $21-28$ \\
\hline$\%$ RA & $50 \mathrm{~min}$ & $50 \mathrm{~min}$ & $67-74$ & $69-72$ \\
\hline \multicolumn{5}{|c|}{ RT Tensile test (transverse) in H1150 condition } \\
\hline $0.2 \% \mathrm{PS}(\mathrm{MPa})$ & $724 \min$ & $724 \min$ & $726-852$ & - \\
\hline UTS (MPa) & $931 \mathrm{~min}$ & $931 \mathrm{~min}$ & $954-978$ & - \\
\hline$\% \mathrm{EL}(\mathrm{Gl}=4 \mathrm{~d})$ & $11 \mathrm{~min}$ & $11 \mathrm{~min}$ & $16-21$ & - \\
\hline$\%$ RA & $35 \mathrm{~min}$ & $35 \mathrm{~min}$ & $43-60$ & - \\
\hline
\end{tabular}


presence of lath martensite and fine spherical carbides of $\mathrm{NbC}$ type (see figure 9). The corresponding transmission electron micrographs revealed lath martensite and fine elliptical $\varepsilon$-copper precipitates of about $45 \mathrm{~nm}$ length and $15 \mathrm{~nm}$ width in $\mathrm{H} 1150$ conditions (figures 10a and b).

Table 7. Subzero and high temperature tensile properties of 15-5 PH martensitic stainless steel.

\begin{tabular}{|c|c|c|c|}
\hline \multirow[b]{2}{*}{ Tensile property } & \multirow[b]{2}{*}{ Literature $[*]$ value } & \multicolumn{2}{|c|}{$\begin{array}{l}\text { Experimentally obtained } \\
\text { values in three melts }\end{array}$} \\
\hline & & Forged bars & Hot rolled bars \\
\hline \multicolumn{4}{|c|}{$-70^{\circ} \mathrm{C}$ Tensile test (longitudinal) in $\mathrm{H} 1025$ condition } \\
\hline $0.2 \% \mathrm{PS}(\mathrm{MPa})$ & 1227 & $1177-1241$ & $1177-1247$ \\
\hline UTS (MPa) & 1280 & $1208-1260$ & $1190-1263$ \\
\hline$\% \mathrm{El}(\mathrm{Gl}=4 \mathrm{~d})$ & - & $18-24$ & $19-22$ \\
\hline$\% \mathrm{RA}$ & - & 60-68 & $64-68$ \\
\hline \multicolumn{4}{|c|}{$200^{\circ} \mathrm{C}$ Tensile test (longitudinal) in $\mathrm{H} 1025$ condition } \\
\hline $0.2 \% \mathrm{PS}(\mathrm{MPa})$ & 894 & 936-979 & 830-974 \\
\hline UTS (MPa) & 955 & $964-1000$ & $869-1000$ \\
\hline$\% \mathrm{EL}(\mathrm{Gl}=4 \mathrm{~d})$ & 9 & $14-17$ & $15-18$ \\
\hline$\%$ RA & 32 & $51-60$ & $59-67$ \\
\hline \multicolumn{4}{|c|}{$300^{\circ} \mathrm{C}$ Tensile test (longitudinal) in $\mathrm{H} 1025$ condition } \\
\hline $0.2 \% \mathrm{PS}(\mathrm{MPa})$ & 819 & 869-919 & $903-935$ \\
\hline UTS (MPa) & 901 & $916-956$ & $941-965$ \\
\hline$\% \mathrm{EL}(\mathrm{Gl}=4 \mathrm{~d})$ & 7 & $14-16$ & $14-17$ \\
\hline$\%$ RA & 36 & $52-59$ & $56-63$ \\
\hline \multicolumn{4}{|c|}{$400^{\circ} \mathrm{C}$ Tensile test (longitudinal) in $\mathrm{H} 1025$ condition } \\
\hline $0.2 \% \mathrm{PS}(\mathrm{MPa})$ & 728 & $811-876$ & $839-874$ \\
\hline UTS (MPa) & 868 & $874-909$ & $889-920$ \\
\hline$\% \mathrm{EL}(\mathrm{Gl}=4 \mathrm{~d})$ & - & $13-16$ & $13-16$ \\
\hline$\%$ RA & - & $54-65$ & $58-63$ \\
\hline \multicolumn{4}{|c|}{$-70^{\circ} \mathrm{C}$ Tensile test (longitudinal) in $\mathrm{H} 1150$ condition } \\
\hline $0.2 \%$ PS (MPa) & 774 & 785-998 & $864-1020$ \\
\hline UTS (MPa) & 1036 & $1093-1117$ & $1046-1115$ \\
\hline$\% \mathrm{El}(\mathrm{Gl}=4 \mathrm{~d})$ & 15 & $23-26$ & $23-26$ \\
\hline$\% \mathrm{RA}$ & 47 & $66-70$ & $69-71$ \\
\hline \multicolumn{4}{|c|}{$200^{\circ} \mathrm{C}$ Tensile test (longitudinal) in $\mathrm{H} 1150$ condition } \\
\hline $0.2 \% \mathrm{PS}(\mathrm{MPa})$ & 701 & $733-838$ & $772-828$ \\
\hline UTS (MPa) & 869 & $807-875$ & $825-867$ \\
\hline$\% \mathrm{EL}(\mathrm{Gl}=4 \mathrm{~d})$ & 12 & $16-20$ & $18-20$ \\
\hline$\%$ RA & 48 & $62-68$ & $65-67$ \\
\hline \multicolumn{4}{|c|}{$300^{\circ} \mathrm{C}$ Tensile test (longitudinal) in $\mathrm{H} 1150$ condition } \\
\hline $0.2 \% \mathrm{PS}(\mathrm{MPa})$ & 667 & $708-795$ & $730-793$ \\
\hline UTS (MPa) & 819 & $769-824$ & $788-867$ \\
\hline$\% \mathrm{EL}(\mathrm{Gl}=4 \mathrm{~d})$ & 9 & $16-18$ & $16-18$ \\
\hline$\%$ RA & 45 & $64-67$ & $64-65$ \\
\hline \multicolumn{4}{|c|}{$400^{\circ} \mathrm{C}$ Tensile test (longitudinal) in $\mathrm{H} 1150$ condition } \\
\hline $0.2 \% \mathrm{PS}(\mathrm{MPa})$ & 620 & $672-736$ & $691-873$ \\
\hline UTS (MPa) & 787 & $731-783$ & 742-909 \\
\hline$\% \mathrm{EL}(\mathrm{Gl}=4 \mathrm{~d})$ & - & $15-19$ & $14-19$ \\
\hline$\%$ RA & - & $61-67$ & $62-66$ \\
\hline
\end{tabular}

*Product Data Sheet of 15-5 PH Stainless Steel, 2007 
The $\varepsilon$-copper precipitates, as stated earlier, provide principal strengthening as they are highly coherent with the matrix and have a Kurdjumov-Sachs $(\mathrm{K}-\mathrm{S})$ orientation relationship with bcc martensite.

\subsection{Hardness}

The alloy exhibited hardness between 279 and 373BHN against specified range of 277 (min)401 ( $\max$ ). The hardness values in different heat treated condition are given in table 4, for the two different mill forms, namely forged and hot-rolled products in the two precipitation hardening conditions of $\mathrm{H} 1025$ and $\mathrm{H} 1150$. These results in three melts show that hardness values obtained are well within the specified range and in narrow scatter band.

\subsection{Impact properties}

Impact strength properties (Charpy and Izod) were determined experimentally and the same are compared with specified values at room temperature as well as at subzero temperature $\left(-70^{\circ} \mathrm{C}\right)$ in longitudinal and transverse directions for forged and hot rolled bars in table 5. The data in table 5 show that the indigenous 15-5 PH stainless steel in both product forms exhibits comparable impact properties with the best reported values of the open literature.

\subsection{Tensile properties}

Forged and hot rolled bars in solution treated condition are quite soft; the $0.2 \%$ proof strength (PS) was $800 \mathrm{MPa}$ and ultimate tensile strength (UTS) was $1000 \mathrm{MPa}$. Tensile tests at room temperature and at elevated temperatures $\left(200^{\circ} \mathrm{C}, 300^{\circ} \mathrm{C}\right.$ and $\left.400^{\circ} \mathrm{C}\right)$ and at subzero temperature $\left(-70^{\circ} \mathrm{C}\right)$ were evaluated and the values obtained are compared with specified literature data in tables 6-8 in case of the present 15-5 PH stainless steel in two different product forms of forged and hot rolled bars in $\mathrm{H} 1025$ and $\mathrm{H} 1150$ aging conditions. These results are shown in tables 6, 7 and 8. In each condition, three samples were tested and results provided in tables 6-8 correspond to their range (minimum and maximum values). The data again show that the indigenous stainless steel is on par with indigenously referred values, if not better. Tensile properties (UTS and $0.2 \% \mathrm{PS}$ ) in figure 11 and ductility (\% elongation and \% reduction in area) in figure 12

Table 8. Low and high cycle fatigue data of 15-5 PH martensitic stainless steel.

\begin{tabular}{|c|c|c|c|c|}
\hline \multirow{2}{*}{$\begin{array}{l}\text { Stress } \\
\text { range } \\
(\mathrm{MPa})\end{array}$} & \multirow{2}{*}{$\begin{array}{l}\text { As per AMS } 5659 \mathrm{H} \\
\text { specified minimum } \\
\text { number of cycles }\end{array}$} & \multirow{2}{*}{$\begin{array}{l}\text { Type test schedule } \\
\text { specified minimum } \\
\text { number of cycles }\end{array}$} & \multicolumn{2}{|c|}{$\begin{array}{l}\text { Experimentally obtained values in } \\
\text { three melts (number of cycles) }\end{array}$} \\
\hline & & & Forged bars & Hot rolled bars \\
\hline \multicolumn{5}{|c|}{ Axial fatigue (smooth) $\mathrm{R}=-1.0 ; \mathrm{K}_{\mathrm{t}}=1 ; \mathrm{F}=30 \mathrm{~Hz}(\mathrm{H} 1025)$} \\
\hline 1048 & $1 \times 10^{5}$ & $1 \times 10^{5}$ & $(1.05-4.77) \times 10^{5}$ & $(1.04-1.10) \times 10^{5}$ \\
\hline 985 & $1 \times 10^{6}$ & $1 \times 10^{6}$ & $(1.03-1.13) \times 10^{6}$ & $(1.03-1.10) \times 10^{6}$ \\
\hline 935 & $1 \times 10^{7}$ & $1 \times 10^{7}$ & $(1.01-1.07) \times 10^{7}$ & $(1.0-1.10) \times 10^{7}$ \\
\hline \multicolumn{5}{|c|}{ Axial fatigue (notch) $\mathrm{R}=-1.0 ; \mathrm{K}_{\mathrm{t}}=3 ; \mathrm{F}=30 \mathrm{~Hz}(\mathrm{H} 1025)$} \\
\hline 345 & $1 \times 10^{4}$ & $1 \times 10^{4}$ & $(1.0-1.16) \times 10^{4}$ & $(1.10-1.18) \times 10^{4}$ \\
\hline 276 & $1 \times 10^{5}$ & $1 \times 10^{5}$ & $(1.01-1.10) \times 10^{5}$ & $(1.08-1.11) \times 10^{5}$ \\
\hline 240 & $1 \times 10^{6}$ & $1 \times 10^{6}$ & $(1.0-1.11) \times 10^{6}$ & $(1.02-1.37) \times 10^{6}$ \\
\hline 205 & $1 \times 10^{7}$ & $1 \times 10^{7}$ & $(1.01-1.53) \times 10^{7}$ & $(1.0-1.10) \times 10^{7}$ \\
\hline
\end{tabular}




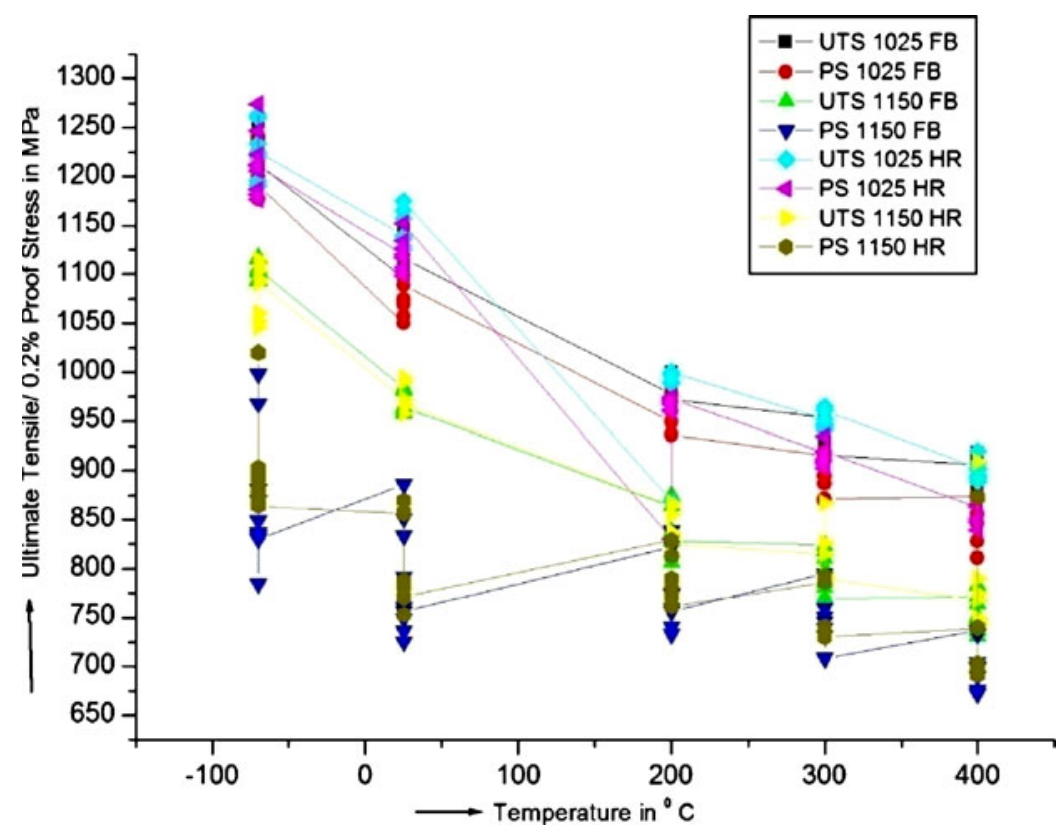

Figure 11. Variation in tensile properties (UTS and $0.2 \%$ PS) with temperature for forged bars and hot rolled bars in H1025 and H1150 aging conditions.

for forged and hot rolled bars were plotted against increased in temperature from $-70,25,200$, 300 and $400^{\circ} \mathrm{C}$. This graph shows (figure 11) that the strength values, both UTS and $0.2 \%$ PS decrease with increase in temperature in H1025 and H1150 aging conditions. Figure 12 where

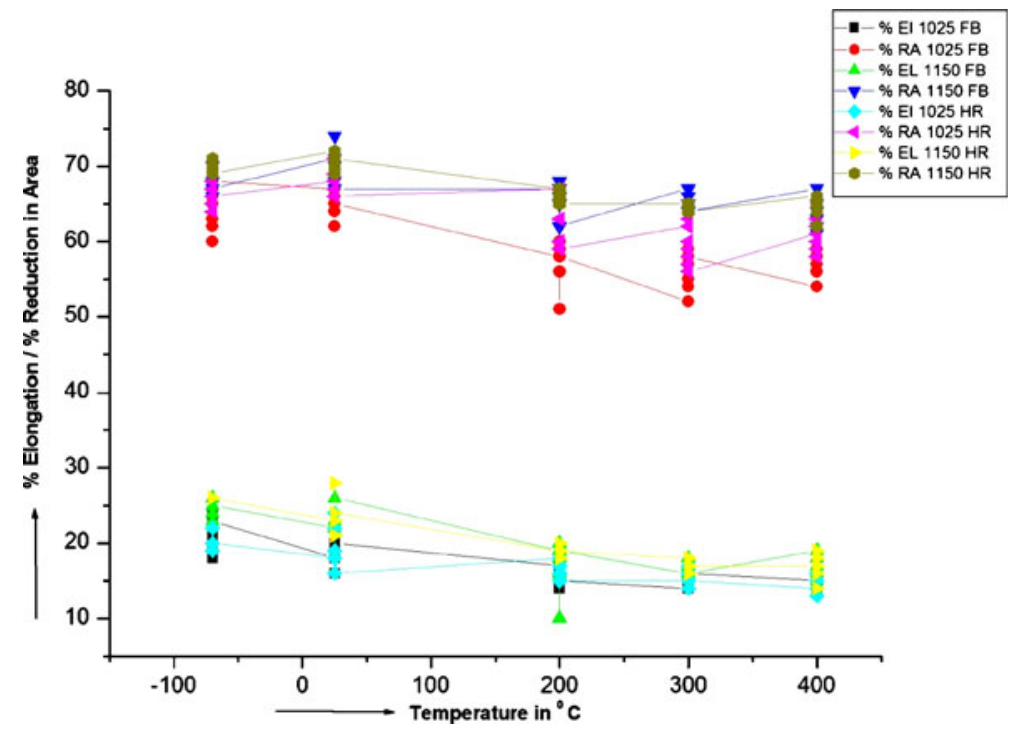

Figure 12. Variation in ductility properties (\% EI and \% RA) with temperature for forged and hot rolled bars in H1025 and H1150 ageing conditions. 
the ductility was plotted as a function of temperature indicates that $\%$ El decreases with increase in temperature, while \% RA decreases with increase in temperature up to $300^{\circ} \mathrm{C}$ and further increase in temperature does not change \%RA. These tests are carried out on three melts and for each melt and each temperature, a minimum three specimens were tested. If any specimen failed during testing not meeting the specified limits, testing was to be carried out twice the number. In subsequent testing if any test specimen failed, no further testing was allowed and the materials were rejected. Hence a total of 27 specimens were tested at each temperature and consistency in these melt batches are shown in tables 6-8 and figures 11 and 12 .

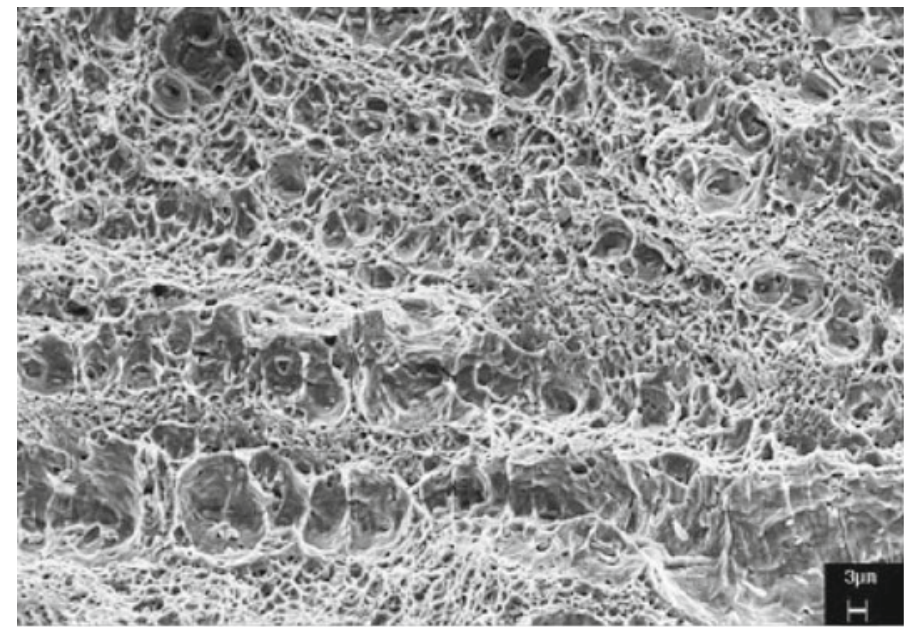

(a)

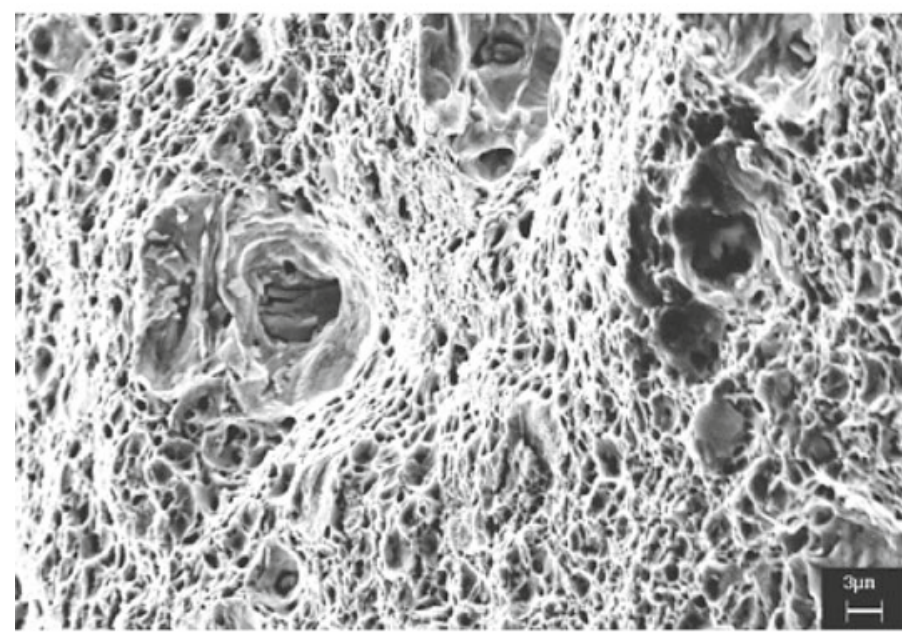

(b)

Figure 13. SEM fractograph showing (a) equiaxed dimples at the central region of the fracture surface of the tensile samples tested at RT. Large dimples aligned in one direction are probably due to inhomogeneous microstructure and not related to delta ferrite which is absent in the steel. (b) SEM fractograph showing large and fine elongated dimples in the shear lip region of the fracture surface of the tensile sample tested at RT. 


\subsection{Fatigue properties}

Fatigue tests in both low and high cycle fatigue regions are conducted at room temperature using smooth and notched specimens. The results obtained were found to be comparable to the level of minimum expected life (see data in table 8). Further, these results are found to

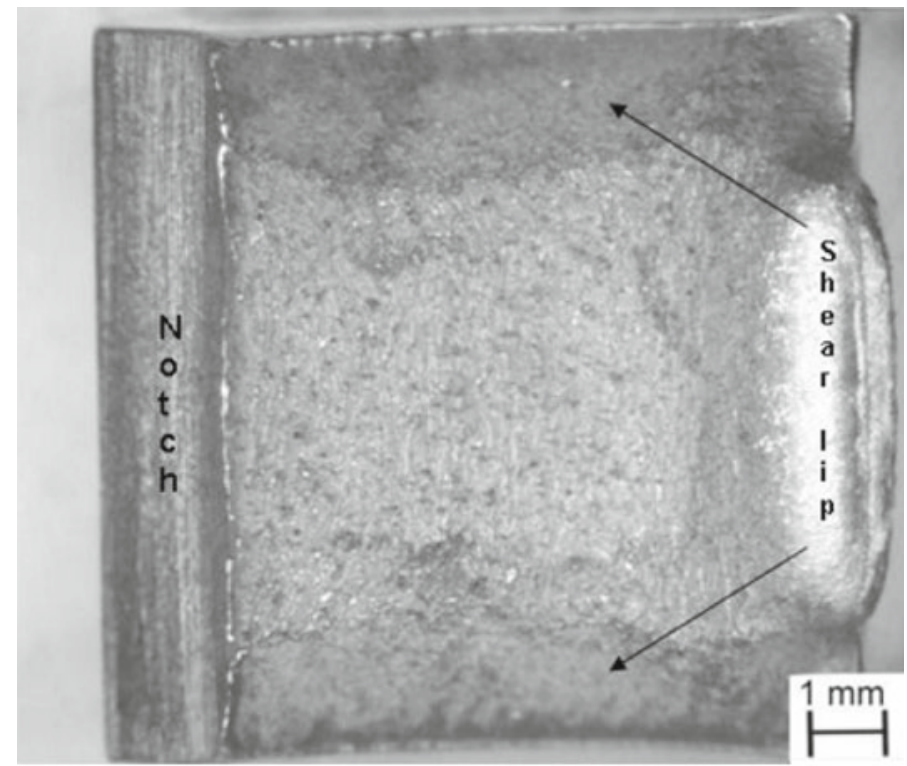

(a)

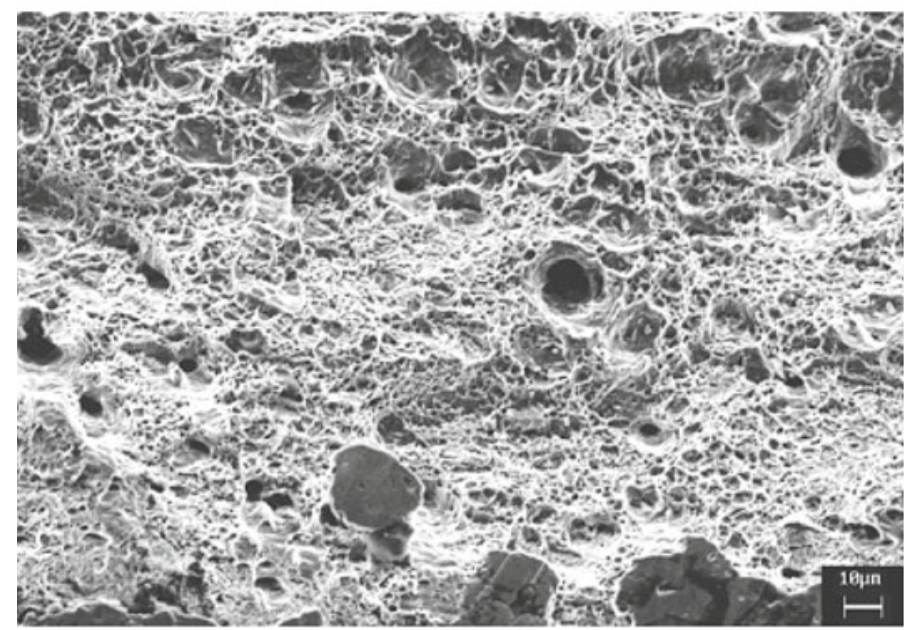

(b)

Figure 14. Stereo fractograph showing (a) the fracture surface of the Izod impact specimen tested at RT. The fracture surface at the centre is fibrous with slight directionality. Extensive shear lip formation is also observed. (b) SEM fractograph showing dimpled rupture in the initiation zone below the notch of the impact specimen tested at RT. Two sizes of dimples are evident. 
be very much comparable to aerospace standards and literature value available in aerospace standards/MIL-standard number, MIL-HDBK-5J (MIL HandBook 2003).

\section{Fractography}

Fractographic investigations were conducted on the fractures surfaces to determine the mode of fracture by subjecting the specimen surfaces obtained from the failed test specimen subjected to tensile, impact and fatigue loading in two ageing conditions of H1025 and H1150. SEM fractograph in figure 13a showing equiaxed dimples at the central region of the fracture surface

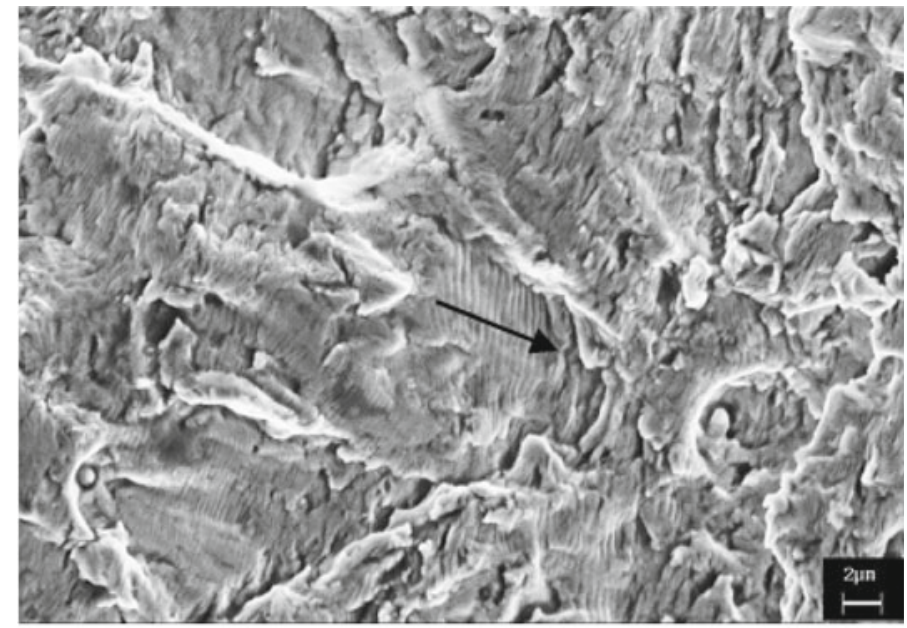

(a)

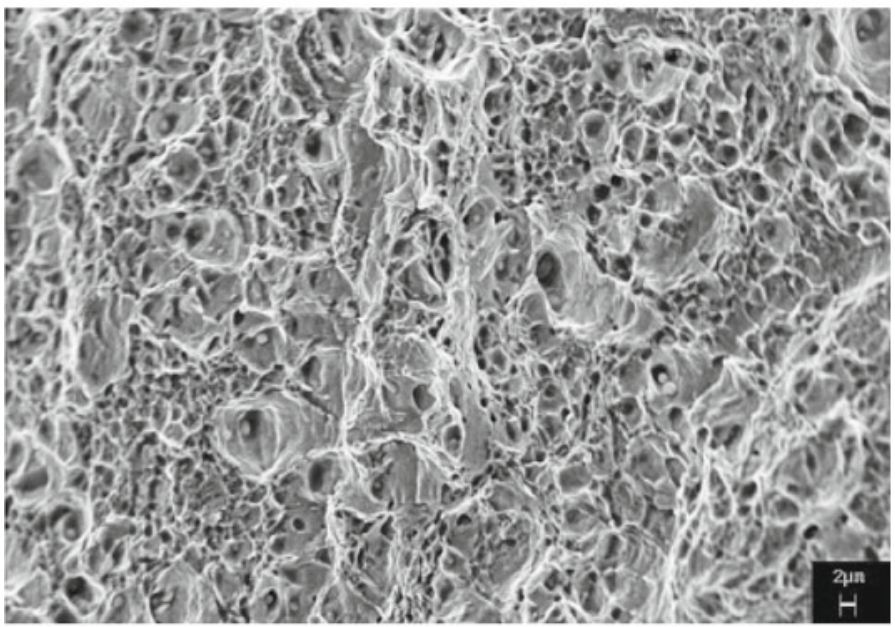

(b)

Figure 15. (a) SEM fractograph showing fatigue striations in the region corresponding to fatigue cracks in $\mathrm{HCF}$ tested specimen. Arrow indicates the crack propagation direction. (b) SEM fractograph showing equiaxed dimples in the region corresponding to final failure in HCF tested specimen. 
of the tensile samples tested at RT. Large dimples aligned in one direction are probably due to inhomogeneous microstructure and not related to delta ferrite which is absent in the steel. SEM fractograph showing in figure $13 \mathrm{~b}$ large and fine elongated dimples in the shear lip region of the fracture surface of the tensile sample tested at RT.

Stereo fractograph showing in figure 14a the fracture surface of the izod impact specimen tested at RT. The fracture surface at the centre is fibrous with slight directionality. Extensive shear lip formation is also observed. SEM fractograph showing in figure $14 \mathrm{~b}$ dimpled rupture in the initiation zone below the notch of the impact specimen tested at RT. The specimen exhibited ductile bimodal distribution of dimple fracture.

SEM fractograph showing figure 15a fatigue striations in the region corresponding to fatigue cracks in HCF tested specimen. Arrow indicates the crack propagation direction. SEM fractograph showing figure $15 \mathrm{~b}$ equiaxed dimples in the region corresponding to final failure in $\mathrm{HCF}$ tested specimen.

\section{Conclusions}

The results obtained from the product 15-5 PH martensitic stainless steel under development programme have yielded the following conclusions.

(i) Martensite laths formed in 15-5 PH stainless steel have been found to contain twins, localized to one side of a lath, which may occur as a result of the accommodation of the shape deformation.

(ii) Precipitation of $\mathrm{Cu}$ occurs during aging in 15-5 PH alloy. The second stage of hardening at higher aging temperature (H1150) is associated with the formation of these precipitates. $\mathrm{Cu}$ precipitates with spherical shapes are probably coherent initially and then transformed to a semi-coherent relationship with the matrix during aging. The orientation relationship is found to be $\mathrm{K}-\mathrm{S}$, commonly found in fcc-bcc systems.

(iii) A small extent of dimple rupture was observed on the fracture surface on specimens fractured under tensile loading. However, based on the SEM observations, it is concluded that the major fracture mode was cleavage and/or quasi-cleavage.

(iv) Without exception, the 15-5 PH steel, developed indigenously, was found to exhibit property (tensile, impact and fatigue) levels that are very much comparable to the best reported in the literature and have far exceeded those specified in Aerospace Material Specifications. Hence, the present steel development programme can further lead to commercial production with airworthiness certification.

(v) Lastly, the consistency among melts and integrity within each melt has been found to be satisfactory and easily matches with that of imported material. The type test schedule with suggested testing programme was found to be adequate for airworthiness certification. The product indigenization programme has helped self-reliance for space and defence programmes of India.

\section{Acknowledgements}

The authors thank Shri M Narayana Rao, Chairman and Managing Director, Mishra Dhantu Nigam, Hyderabad, India as well as Dr. A V Reddy and Dr. V K Varma, Former Regional Directors, RCMA (Mat) for their contributions and active participation. Financial support, from Defence Research Development Organization (DRDO) and Ministry of Defence (Production) of the Indian Government, is gratefully acknowledged. 


\section{References}

AMS 2241N 2003 Aeronautical material specification for inspection, tolerances, corrosion and heat resistant steel, iron alloy, titanium and titanium alloy bars and wire, Warrendale, PA: Society of Automotive Engineers

AMS 2248E 2000 Aeronautical material specification, chemical check analysis limits, corrosion and heat resistance steels and alloys, maraging and other highly alloyed steels, and iron alloys, Warrendale, PA: Society of Automotive Engineers

AMS 2315E 2001 Aeronautical material specification for determination of delta ferrite content, Warrendale, PA: Society of Automotive Engineers

AMS 2630B 1995 Aeronautical material specification for inspection, ultrasonic product over 0.5 inch $(12.7 \mathrm{~mm})$ thick, Warrendale, PA: Society of Automotive Engineers

AMS 5659L 2004 Aeronautical material specification, steel corrosion resistant, bars, wire, forgings, rings and extrusions, $15 \mathrm{Cr}-4.5 \mathrm{Ni}-0.30 \mathrm{Cb}-3.5 \mathrm{Cu}$. Consumable electrode melted solution heat treated, precipitation hardenable, Warrendale, PA: Society of Automotive Engineers

Armco 15-5 PH VAC CE or ESR AMS 5659-II, Precipitation hardening stainless steel, Armco Product data bulletin No. S-21C, Middle Town, Ohio: Armco Steel Corporation

ASTM A604 2007 Standard test method for macroetch testing of consumable electrode remelted steel bars and billets, West Conshonhocken, PA: American Society for Testing and Materials

ASTM E 10192003 Standard test methods for determination of carbon, sulphur, nitrogen and oxygen in steel and in iron, nickel and cobalt alloys, West Conshonhocken, PA: American Society for Testing and Materials

ASTM E 1121996 Standard test methods for determining average grain size of metals, West Conshonhocken, PA: American Society for Testing and Materials

ASTM E 451997 Standard test methods for determining the inclusion content of steel, West Conshonhocken, PA: American Society for Testing and Materials

ASTM E 4662007 Standard practice for conducting force controlled constant amplitude axial fatigue tests of metallic materials, West Conshonhocken, PA: American Society for Testing and Materials

ASTM E 82004 Standard test method for tension testing of metallic materials, West Conshonhocken, PA: American Society for Testing and Materials

ASTM E-10 1998 Standard test method for brinell hardness of metallic materials, West Conshonhocken, PA: American Society for Testing and Materials

ASTM E-21 1998 Standard test method elevated temperature tension test of metallic materials, West Conshonhocken, PA: American Society for Testing and Materials

ASTM E353 1993 Standard test methods for chemical analysis of stainless, heat resisting, maraging and other similar chromium-nickel-iron alloys, West Conshonhocken, PA: American Society for Testing and Materials

BS-5S100 1993 British standard aerospace series: Procedure for inspection, testing and acceptance of wrought steels (other than plate, sheet, strip and tube), London

John L and Shannon J R 1969 Aerospace structural metals handbook, volume 2 - Ferrous alloys, Ohio, USA: Battelle Columbus Laboratories

Military HandBook, MIL-HDBK-5J 2003 Military standards, metallic materials and elements for aerospace vehicle structures

Military HandBook, MIL-HDBK-6875 1993 Military specification, heat treatment of steel raw materials

Military Standard, MIL-STD-163 1988 Military standard steel mill products, prepared for shipment and storage

Product Data Sheet of 15-5 PH 2007 Stainless Steel, West Chester, Ohio: AK Steel Corporation

Type Approval Document for 15-5 2004 Precipitation hardening stainless steel, Mishra Dhatu Nigam Limited

Type Test Schedule for 15-5 PH 2001 For forged and hot rolled bars, RCMA (M)/76 